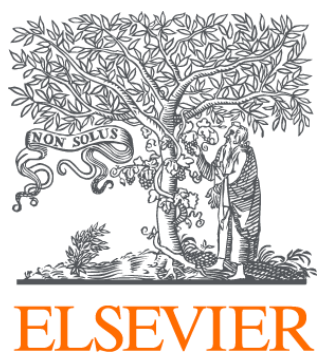

Since January 2020 Elsevier has created a COVID-19 resource centre with free information in English and Mandarin on the novel coronavirus COVID-

19. The COVID-19 resource centre is hosted on Elsevier Connect, the company's public news and information website.

Elsevier hereby grants permission to make all its COVID-19-related research that is available on the COVID-19 resource centre - including this research content - immediately available in PubMed Central and other publicly funded repositories, such as the WHO COVID database with rights for unrestricted research re-use and analyses in any form or by any means with acknowledgement of the original source. These permissions are granted for free by Elsevier for as long as the COVID-19 resource centre remains active. 


\title{
Inhibition of the replication of SARS-CoV-2 in human cells by the FDA-approved drug chlorpromazine
}

\author{
Marion Plaze ${ }^{\mathrm{a}, \mathrm{b}, \dagger}$, David Attali ${ }^{\mathrm{a}, \mathrm{b}, \mathrm{c}, \dagger}$, Matthieu Prot ${ }^{\mathrm{d}, \dagger}$, Anne-Cécile Petit ${ }^{\mathrm{a}, \mathrm{e}}$, Michael Blatzer ${ }^{\mathrm{e}}$, \\ Fabien Vinckier ${ }^{\mathrm{a}}{ }^{\mathrm{b}}$, Laurine Levillayer ${ }^{\mathrm{f}}$, Jeanne Chiaravallig, Florent Perin-Dureau ${ }^{\mathrm{h}}$, \\ Arnaud Cachia ${ }^{i, j}$, Gérard Friedlander ${ }^{b}$, Fabrice Chrétien ${ }^{b, e, k, \ddagger}$, Etienne Simon-Loriere ${ }^{\mathrm{d}, \ddagger}$, \\ Raphaël Gaillard a,b,e,t,*,
}

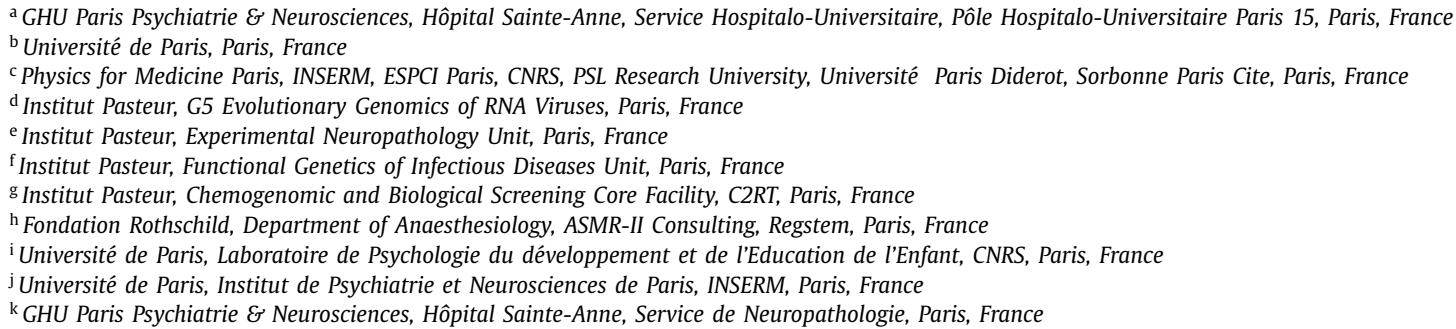

\section{A R T I C L E I N F O}

\section{Article history:}

Received 15 June 2020

Accepted 20 December 2020

editor: Dr Jim Gray

\section{Keywords:}

Chlorpromazine

SARS-CoV-2

COVID-19

Repurposing of molecules

Human cells

\begin{abstract}
A B S T R A C T
Introduction: Urgent action is needed to fight the ongoing coronavirus disease 2019 (COVID-19) pandemic by reducing the number of infected cases, contagiousness and severity. Chlorpromazine (CPZ), an antipsychotic from the phenothiazine group, is known to inhibit clathrin-mediated endocytosis and has antiviral activity against severe acute respiratory syndrome coronavirus-1 (SARS-CoV-1) and Middle East respiratory syndrome coronavirus. The aim of this in-vitro study was to test CPZ against SARS-CoV-2 in monkey and human cells.

Materials and methods: Monkey VeroE6 cells and human alveolar basal epithelial A549-ACE2 cells were infected with SARS-CoV-2 in the presence of various concentrations of CPZ. Supernatants were harvested at day 2 and analysed by quantitative reverse transcription polymerase chain reaction (RT-qPCR) for the presence of SARS-CoV-2 RNA. Cell viability was assessed in non-infected cells.

Results: CPZ was found to have antiviral activity against SARS-CoV-2 in monkey VeroE6 cells, with a half maximal inhibitory concentration $\left(\mathrm{IC}_{50}\right)$ of $8.2 \mu \mathrm{M}$, half maximal cytotoxic concentration $\left(\mathrm{CC}_{50}\right)$ of 13.5 $\mu \mathrm{M}$, and selectivity index (SI) of 1.65. In human A549-ACE2 cells, CPZ was also found to have anti-SARSCoV-2 activity, with $\mathrm{IC}_{50}$ of $11.3 \mu \mathrm{M}, \mathrm{CC}_{50}$ of $23.1 \mu \mathrm{M}$ and SI of 2.04 .

Discussion: Although the measured SI values are low, the $\mathrm{IC}_{50}$ values measured in vitro may translate to $\mathrm{CPZ}$ dosages used in routine clinical practice because of the high biodistribution of CPZ in lungs and saliva. Also, the distribution of $\mathrm{CPZ}$ in brain could be of interest for treating or preventing neurological and psychiatric forms of COVID-19.

Conclusions: These preclinical findings support clinical investigation of the repurposing of CPZ, a drug with mild side effects, in the treatment of patients with COVID-19.
\end{abstract}

(c) 2021 Elsevier Ltd and International Society of Antimicrobial Chemotherapy. All rights reserved.

* Corresponding author. Address: GHU Paris Psychiatrie \& Neurosciences, 1 rue Cabanis, 75014 Paris, France.

E-mail address: r.gaillard@ghu-paris.fr (R. Gaillard).

$\dagger$ Joint first authors.

$\ddagger$ These authors co-supervised this work. 


\section{Introduction}

From the beginning of the coronavirus disease 2019 (COVID2019) outbreak, a higher prevalence of symptomatic and severe forms of COVID-19 was observed at Sainte-Anne Hospital (GHU Paris Psychiatrie \& Neurosciences, Paris, France) among healthcare professionals $(\sim 14 \%)$ compared with patients on psychiatric wards $(\sim 4 \%)$ [1]. This unexpected finding [i.e. that patients with more comorbidities and risk factors (e.g. overweight, cardiovascular disorders, etc.) seem to be protected against symptomatic and severe forms of COVID-19] led to investigate putative factors that could mediate this protection against severe acute respiratory syndrome coronavirus-2 (SARS-CoV-2). As patients in psychiatric wards receive psychotropic medications, the literature was searched for antipsychotic drugs with antiviral effects.

This literature search identified chlorpromazine (CPZ), an antipsychotic from the phenothiazine group, as the lead candidate [1] for multiple reasons. Firstly, in addition to its antipsychotic activity, CPZ has been used for decades in virology. In-vitro studies have demonstrated that $\mathrm{CPZ}$ has antiviral properties against, for example, influenza [2], hepatitis viruses [3], alphaviruses [4], John Cunningham virus [5], Japanese encephalitis virus [6], bronchitis virus [7], MHV-2 [8], Zika virus [9] and dengue virus [10]. In addition, $\mathrm{CPZ}$ is the leading drug inhibiting clathrin-mediated endocytosis [11-14] - via translocation of clathrin and AP2 from the cell surface to intracellular endosomes [12] - and therefore is commonly used to determine the pathways of entry of viruses into cells [11-14]. A recent review article underlined the therapeutic potential of targeting clathrin-mediated endocytosis - essential for entry of coronaviruses into cells [15] - to tackle SARS-CoV-2 [16].

Secondly, CPZ has been shown to have antiviral activity against coronaviruses in multiple studies [17-20]. It was identified as active against both Middle East respiratory syndrome coronavirus (MERS-CoV) and SARS-CoV-1 in a screen of 348 drugs approved by the US Food and Drug Administration (FDA), together with three other compounds (chloroquine, loperamide, lopinavir), using different cell lines [17]. Similar results were obtained in a different library screen [18], as well as in another study using primary human monocytes [19]. More recently, CPZ (and 16 other compounds) has been shown to have antiviral activity against SARS-CoV-2 in monkey Vero E6 cells [20].

As such, the aim of this study was to investigate in-vitro $\mathrm{CPZ}$ antiviral activity against SARS-CoV-2 in monkey Vero E6 cells and - for the first time - human alveolar basal epithelial cells.

\section{Materials and methods}

\subsection{Cell culture and virus isolates}

Vero E6 cells (African green monkey kidney epithelial cells, ATCC, CRL-1586) were maintained in Dulbecco's modified Eagle's medium (DMEM) containing 10\% fetal bovine serum (FBS), 5 units $/ \mathrm{mL}$ penicillin and $5 \mu \mathrm{g} / \mathrm{mL}$ streptomycin at $37^{\circ} \mathrm{C}$ with $5 \% \mathrm{CO}_{2}$. A549-ACE2 cells (adenocarcinomic human alveolar basal epithelial cells, transduced to express human angiotensin-converting enzyme 2; kind gift from Pr. O. Schwartz, Institut Pasteur, Paris France) were maintained in DMEM containing 10\% FBS, 5 units $/ \mathrm{mL}$ penicillin, $5 \mu \mathrm{g} / \mathrm{mL}$ streptomycin and $40 \mu \mathrm{g} / \mathrm{mL}$ blasticidin at $37^{\circ} \mathrm{C}$ with $5 \% \mathrm{CO}_{2}$.

SARS-CoV-2 (isolate BetaCoV/France/IDF0372/2020 C2) was supplied by the National Reference Centre for Respiratory Viruses (NRC) at Institut Pasteur, Paris, France, headed by Pr. S. Van der Werf. The human sample from which this strain was isolated was provided by $\operatorname{Dr} \mathrm{X}$. Lescure and $\operatorname{Pr}$ Y. Yazdanpanah from Bichat
Hospital, Paris, France. Viral stocks were prepared by propagation in VeroE6 cells in DMEM supplemented with 2\% FBS. Viral titres were determined by plaque assay. All experiments involving live SARS-CoV-2 were performed in accordance with the guidelines of Institut Pasteur for Biosafety Level 3 work. All experiments were performed in at least three biologically independent replicates.

\subsection{Antiviral activity assay}

Cells were seeded into 96 -well plates $24 \mathrm{~h}$ prior to the experiment. Two hours prior to infection, cell culture supernatant was replaced with media containing $32 \mu \mathrm{M}, 16 \mu \mathrm{M}, 8 \mu \mathrm{M}, 4 \mu \mathrm{M}$ or $2 \mu \mathrm{M}$ of $\mathrm{CPZ}$, or the equivalent volume of water (control). For infection, the drug-containing media was removed and replaced with virus inoculum [multiplicity of infection values of 0.1 plaque-forming units (PFU)/cell for VeroE6 cells and 1 for A549-ACE2 cells] for 2 h. The inoculum was then removed and replaced with $100 \mu \mathrm{L}$ of fresh media ( $2 \% \mathrm{FBS}$ ) containing $\mathrm{CPZ}$ at the indicated concentration or water and incubated for $48 \mathrm{~h}$.

At $48 \mathrm{~h}$, cell supernatant was collected and spun for $5 \mathrm{~min}$ at $3000 \mathrm{~g}$ to remove debris. Toxicity controls were set up in parallel on uninfected cells. RNA was extracted from $50-\mu \mathrm{L}$ aliquots of supernatant using the Nucleospin 96 virus kit (Macherey-Nagel, Düren, Germany) in accordance with the manufacturer's instructions. Detection of viral genomes was performed by quantitative reverse transcription polymerase chain reaction (RT-qPCR) using the IP4 primer set developed by NRC at Institut Pasteur (described on the World Health Organization's website: https: //www.who.int/docs/default-source/coronaviruse/real-time-rt-pcrassays-for-the-detection-of-sars-cov-2-institut-pasteur-paris.pdf? sfvrsn=3662fcb6_2). RT-qPCR was performed using the Luna Universal One-Step RT-qPCR Kit (New England Biolabs, Ipswich, MA, USA) in a QuantStudio 3 thermocycler (Applied Biosystems, Foster City, CA, USA) with the following cycling conditions: $55^{\circ} \mathrm{C}$ for 10 $\min , 95^{\circ} \mathrm{C}$ for $1 \mathrm{~min}$, and 40 cycles at $95^{\circ} \mathrm{C}$ for $10 \mathrm{~s}$, followed by $60^{\circ} \mathrm{C}$ for $1 \mathrm{~min}$. The quantity of viral genomes is expressed as PFU equivalents, and was calculated by using a standard curve with RNA derived from viral stock with a known viral titre.

Cell viability in drug-treated cells was measured using alamarBlue reagent (ThermoFisher, Waltham, MA, USA). Forty-eight hours post treatment, the drug-containing media was removed and replaced with alamarBlue and incubated for $2 \mathrm{~h}$ at $37^{\circ} \mathrm{C}$. Fluorescence was measured using an Infinite 200 PRO plate reader (Tecan, Männedorf, Switzerland).

Using the same experimental setting, the antiviral activity of remdesivir was tested as a comparator and validator of the experiment.

\subsection{Data analysis}

Antiviral activity was assayed as a percentage of inhibition of SARS-CoV-2, normalized to the quantity of viral genomes at the lowest concentration of CPZ (i.e. $2 \mu \mathrm{M}$ ) for each of the three independent replicates. Percentage cytotoxicity was calculated relative to untreated cells ( $0 \%$ toxicity). Antiviral activity and cytoxicity data were analysed using GraphPad Prism Version 8.4.2 for MacOS (GraphPad Software, San Diego, CA, USA; www.graphpad.com). Non-linear regressions were performed and the half maximal inhibitory concentration $\left(\mathrm{IC}_{50}\right), 90 \%$ maximal inhibitory concentration $\left(\mathrm{IC}_{90}\right)$, half maximal cytotoxic concentration $\left(\mathrm{CC}_{50}\right)$ and selectivity index ( $\mathrm{SI}$; calculated by dividing $\mathrm{CC}_{50}$ by $\mathrm{IC}_{50}$ ) were calculated from '[agonist] vs. response - variable slope' curves with constraints to remain above $0 \%$ and below $100 \%$. 
A

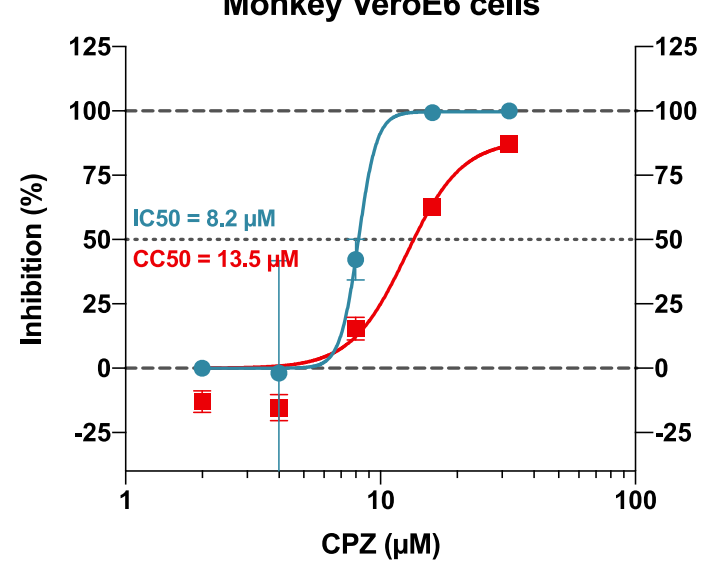

B

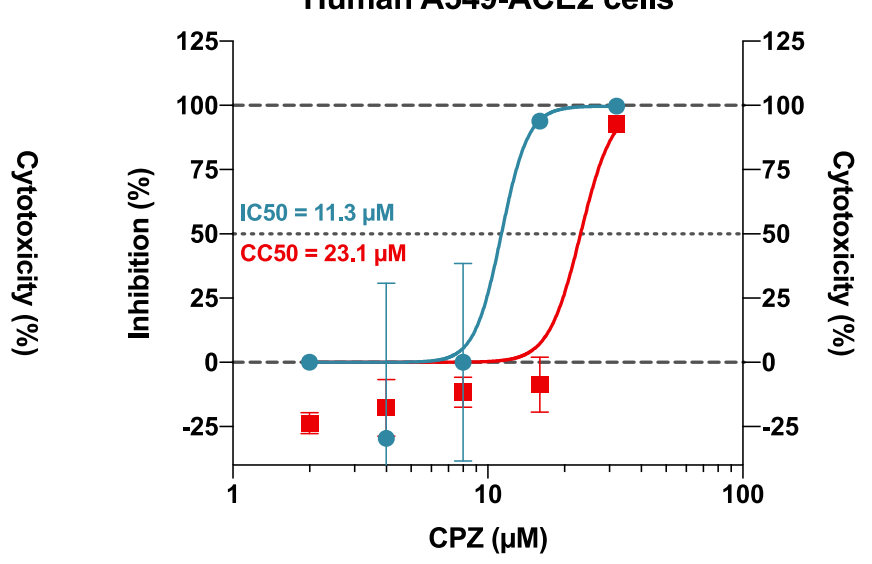

$\rightarrow$ Antiviral activity $\rightarrow$ Cytotoxicity

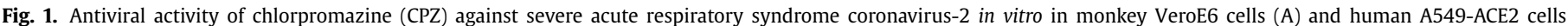

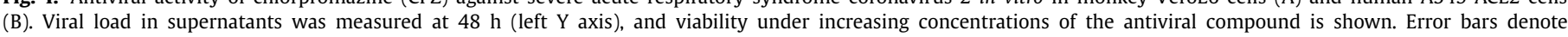
standard error of the mean. $\mathrm{IC}_{50}$, half maximal inhibitory concentration; $\mathrm{CC}_{50}$, half maximal cytotoxic concentration.

\section{Results}

African green monkey VeroE6 cells and human alveolar basal epithelial A549-ACE2 cells were infected with SARS-CoV-2 in the presence of various concentrations of CPZ. Supernatants were harvested at day 2 and analysed by RT-qPCR for the presence of SARSCoV-2 RNA. In parallel, cell viability was assessed in non-infected cells.

In monkey VeroE6 cells, $\mathrm{CPZ}$ was found to have antiviral activity against SARS-CoV-2, with $\mathrm{IC}_{50}$ of $8.2 \mu \mathrm{M}, \mathrm{IC}_{90}$ of $15.2 \mu \mathrm{M}, \mathrm{CC}_{50}$ of $13.5 \mu \mathrm{M}$ and SI of 1.65 (Fig. 1A).

In human A549-ACE2 cells, CPZ was also associated with antiSARS-CoV-2 activity, with $\mathrm{IC}_{50}$ of $11.3 \mu \mathrm{M}$ (Fig. $1 \mathrm{~B}$ ) and $\mathrm{IC}_{90}$ of $14.3 \mu \mathrm{M}$. CPZ had a cytotoxic effect in human A549-ACE2 cells at the highest doses assessed, with $\mathrm{CC}_{50}$ of $23.1 \mu \mathrm{M}$ and SI of 2.04 (Fig. 1B).

Remdesivir was found to have antiviral activity against SARSCoV-2, with $\mathrm{IC}_{50}$ values of $5 \mu \mathrm{M}$ and $0.15 \mu \mathrm{M}$ in monkey VeroE6 cells and human A549-ACE2 cells, respectively.

\section{Discussion}

With more than 6000000 infections and 370000 deaths worldwide in just a few months [21], tools are needed urgently to reduce the severity and contagiousness of COVID-19, and reduce the socio-economic consequences. This study evidenced invitro antiviral activity of $\mathrm{CPZ}$ against SARS-CoV-2 in monkey and human cells, with $\mathrm{IC}_{50}$ values of 8.2 and $11.3 \mu \mathrm{M}$, respectively. These results are in line with previous demonstrations of antiviral properties of $\mathrm{CPZ}$, a well-known inhibitor of clathrin-mediated endocytosis [11-14], against other coronaviruses. In addition, the $\mathrm{IC}_{50}$ of remdesivir is consistent with previously published work [22,23], reinforcing the validation of the experimental setup.

Although the measured SI values of $\mathrm{CPZ}$ are very low, the $\mathrm{IC}_{50}$ values measured in vitro may translate to $\mathrm{CPZ}$ dosages used in routine clinical practice. Indeed, one of the main advantages of using CPZ against SARS-CoV-2 could lie in its biodistribution (Fig. 2), and mainly and foremost in its pneumophilic properties. In 1968, Forrest et al. quantified the distribution of CPZ in selected organs through a post-mortem study of six patients with schizophrenia who were treated with $\mathrm{CPZ}$ until death [24]. Among the five patients with lung measurements available, the highest CPZ concentration was found in the lungs. High pneumophilic properties of

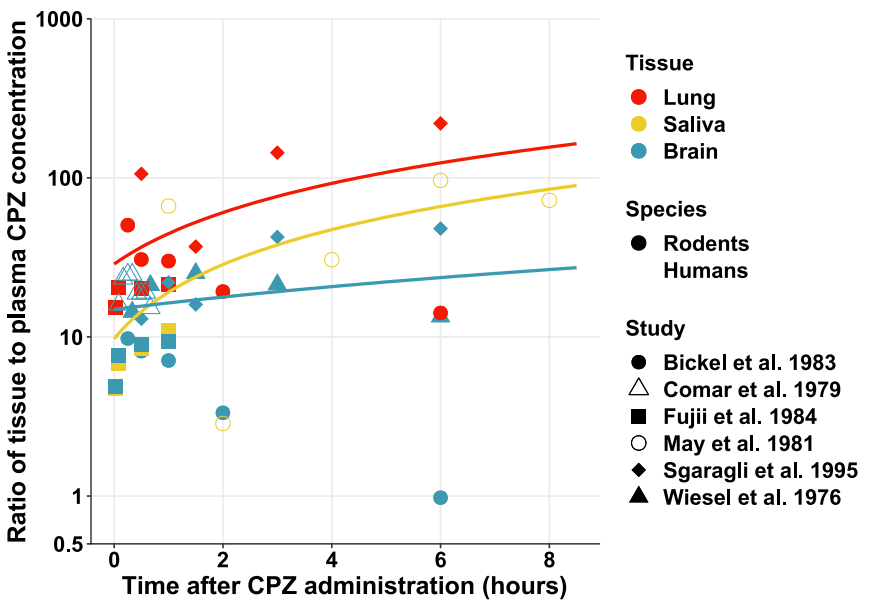

Fig. 2. Review of temporal distribution of chlorpromazine (CPZ) in lungs, saliva and brain. Ratio of tissue to plasma CPZ concentrations (log scale) after administration of a single dose of $\mathrm{CPZ}$ are represented for lungs (red), saliva or salivary glands (yellow) and brain (blue) in rodents (solid symbols) and humans (open symbols). Derived from previous preclinical and clinical studies [25-28,31,32].

CPZ have also been described in preclinical studies, reporting a lung concentration of $\mathrm{CPZ}$ that is 20-200 times higher than the plasma concentration of CPZ after a single dose [24-27]. Besides the lungs, CPZ concentrations have been demonstrated to be 30100 times higher in the salivary glands compared with plasma after a single dose of $\mathrm{CPZ}[26,28]$. In humans, May et al. studied the salivary concentration of $\mathrm{CPZ}$ in 48 newly admitted patients with schizophrenia, and found concentrations between 1300 and $22000 \mathrm{ng} / \mathrm{mL}$ (i.e. 4.1-69 $\mu \mathrm{M}$; CPZ molar mass = $318.86 \mathrm{~g} / \mathrm{mol}$ ) 1-8 h after a single dose of CPZ [28]. These high salivary concentrations of CPZ could reduce the contagiousness of COVID-19 [29]. Moreover, because of its lipophilic nature, CPZ crosses the bloodbrain barrier [30]. Distribution of CPZ in the brain, underlying its antipsychotic action and side effects, has been described, with a $\mathrm{CPZ}$ concentration in brain up to 50 times higher compared with the CPZ concentration in plasma in rodents [25-27,31]. In humans, the distribution of $\mathrm{CPZ}$ in the brain was studied in 22 patients with schizophrenia at the study hospital in 1979, with the brain:plasma ratio ranging from 15 to 25 [32]. This could be of interest for treat- 
ing or preventing neurological and psychiatric forms of COVID-19 [33], which, to date, have no available therapeutic options. Indeed, remdesivir, the anti-interleukin-6 drug tocilizumab and hydroxychloroquine, three of the most studied drugs in the treatment of COVID-19, do not cross the blood-brain barrier or cross it to a far lesser extent [34-37].

Overall, although the extrapolation from an in-vitro result to a clinically relevant dose is not straightforward, the $\mathrm{IC}_{50}$ of $11.3 \mu \mathrm{M}$ (i.e. $3603 \mathrm{ng} / \mathrm{mL}$ ) measured in vitro in human cells may be compatible with $\mathrm{CPZ}$ dosages used in routine clinical practice. Indeed, residual plasma levels of $\mathrm{CPZ}$ in patients range from 30 to 300 $\mathrm{ng} / \mathrm{mL}$ [38], which could correspond to $600-60000 \mathrm{ng} / \mathrm{mL}$ in lungs [24-27] and 900-30 $000 \mathrm{ng} / \mathrm{mL}$ in saliva [26,28] (Fig. 2). This extrapolation is supported by the observation of a lower prevalence of symptomatic and severe forms of COVID-19 in psychiatric patients.

Repurposing CPZ, a molecule already used in clinical practice, could offer a ready-to-use treatment with well-known and very mild side effects. CPZ has been widely used in clinical practice for the treatment of acute and chronic psychoses for decades. This first antipsychotic medication was discovered in 1952 by Jean Delay and Pierre Deniker at Sainte-Anne Hospital [39]. CPZ has been prescribed for approximately 70 years and has been approved by the US FDA for use in psychiatry and anaesthesiology, with an excellent tolerance profile. CPZ is also used in refractory nausea and vomiting of pregnancy [40], in advanced cancer [41], and to treat refractory headaches in various neurological conditions [42].

\section{Conclusions}

This first in-vitro study of the antiviral activity of CPZ against SARS-CoV-2 in monkey and human cells supports that CPZ, a wellknown drug with antiviral properties and an excellent tolerance profile, could be tested clinically as an alternative to currently used drugs or combinations of drugs for the treatment of COVID-19. This proof of principle for the feasibility of CPZ to treat COVID-19 is a critical step for a future clinical trial (NCT04366739).

\section{Acknowledgements}

The authors wish to thank the Centre National de Reference des virus des infections respiratoires for sharing reagents and protocols, Olivier Schwartz and his team for sharing the A549-ACE2 cell line, and the Fondation Pierre Deniker for its support.

Funding: This study has received funding from Institut Pasteur (covid-therap), from the French Government's Investissement d'Avenir programme and as a recognition as a Laboratoire d'Excellence 'Integrative Biology of Emerging Infectious Diseases' (Grant No. ANR-10-LABX-62-IBEID). ESL acknowledges funding from the INCEPTION programme (Investissements d'Avenir Grant ANR-16-CONV-0005).

Competing interests: None declared.

Ethical approval: Not required.

\section{References}

[1] Plaze M, Attali D, Petit A-C, Blatzer M, Simon-Loriere E, Vinckier F, et al. Repositionnement de la chlorpromazine dans le traitement du COVID-19: étude reCoVery. L’Encéphale 2020;46(Suppl.):S35-9.

[2] Krizanová O, Ciampor F, Veber P. Influence of chlorpromazine on the replication of influenza virus in chick embryo cells. Acta Virol 1982;26:209-16.

[3] Blanchard E, Belouzard S, Goueslain L, Wakita T, Dubuisson J, Wychowski C, et al. Hepatitis $C$ virus entry depends on clathrin-mediated endocytosis. J Virol 2006;80:6964-72.

[4] Pohjala L, Utt A, Varjak M, Lulla A, Merits A, Ahola T, et al. Inhibitors of alphavirus entry and replication identified with a stable chikungunya replicon cell line and virus-based assays. PLoS One 2011;6:e28923.

[5] Pho MT, Ashok A, Atwood WJ. JC virus enters human glial cells by clathrin-dependent receptor-mediated endocytosis. J Virol 2000;74:2288-92.
[6] Nawa M, Takasaki T, Yamada K-I, Kurane I, Akatsuka T. Interference in Japanese encephalitis virus infection of Vero cells by a cationic amphiphilic drug, chlorpromazine. J Gen Virol 2003;84:1737-41.

[7] Chu VC, McElroy LJ, Ferguson AD, Bauman BE, Whittaker GR. Avian infectious bronchitis virus enters cells via the endocytic pathway. Adv Exp Med Biol 2006;581:309-12.

[8] Pu Y, Zhang X. Mouse hepatitis virus type 2 enters cells through a clathrinmediated endocytic pathway independent of Eps15. J Virol 2008;82:8112-23.

[9] Persaud M, Martinez-Lopez A, Buffone C, Porcelli SA, Diaz-Griffero F. Infection by Zika viruses requires the transmembrane protein AXL, endocytosis and low pH. Virology 2018;518:301-12.

[10] Carro AC, Piccini LE, Damonte EB. Blockade of dengue virus entry into myeloid cells by endocytic inhibitors in the presence or absence of antibodies. PLoS Negl Trop Dis 2018;12:e006685.

[11] Daniel JA, Chau N, Abdel-Hamid MK, Hu L, von Kleist L, Whiting A, et al. Phenothiazine-derived antipsychotic drugs inhibit dynamin and clathrin-mediated endocytosis. Traffic 2015;16:635-54.

[12] Wang LH, Rothberg KG, Anderson RG. Mis-assembly of clathrin lattices on endosomes reveals a regulatory switch for coated pit formation. J Cell Biol 1993;123:1107-17.

[13] Chen F, Zhu L, Zhang Y, Kumar D, Cao G, Hu X, et al. Clathrin-mediated endocytosis is a candidate entry sorting mechanism for Bombyx mori cypovirus. Sci Rep 2018;8:7268.

[14] Inoue Y, Tanaka N, Tanaka Y, Inoue S, Morita K, Zhuang M, et al. Clathrin-dependent entry of severe acute respiratory syndrome coronavirus into target cells expressing ACE2 with the cytoplasmic tail deleted. J Virol 2007:81:8722-9

[15] Burkard C, Verheije MH, Wicht O, van Kasteren SI, van Kuppeveld FJ, Haagmans BL, et al. Coronavirus cell entry occurs through the endo-/lysosomal pathway in a proteolysis-dependent manner. PLoS Pathog 2014;10:e1004502.

[16] Yang N, Shen H-M. Targeting the endocytic pathway and autophagy process as a novel therapeutic strategy in COVID-19. Int J Biol Sci 2020;16:1724-31.

[17] de Wilde AH, Jochmans D, Posthuma CC, Zevenhoven-Dobbe JC, van Nieuwkoop S, Bestebroer TM, et al. Screening of an FDA-approved compound library identifies four small-molecule inhibitors of Middle East respiratory syndrome coronavirus replication in cell culture. Antimicrob Agents Chemother 2014;58:4875-84.

[18] Dyall J, Coleman CM, Hart BJ, Venkataraman T, Holbrook MR, Kindrachuk J, et al. Repurposing of clinically developed drugs for treatment of Middle East respiratory syndrome coronavirus infection. Antimicrob Agents Chemother 2014;58:4885-93.

[19] Cong Y, Hart B], Gross R, Zhou H, Frieman M, Bollinger L, et al. MERS$\mathrm{CoV}$ pathogenesis and antiviral efficacy of licensed drugs in human monocyte-derived antigen-presenting cells. PLoS One 2018;13:e0194868.

[20] Weston S, Coleman CM, Haupt R, Logue J, Matthews K, Li Y, et al. Broad anti-coronaviral activity of FDA approved drugs against SARS-CoV-2 in vitro and SARS-CoV in vivo. J Virol 2020;94:e01218-20.

[21] European Centre for Disease Prevention and Control COVID-19 situation update worldwide, as of 1 June 2020, Stockholm: ECDC; 2020. Available at: https: //www.ecdc.europa.eu/en/geographical-distribution-2019-ncov-cases [last accessed 1 June 2020]

[22] Wang M, Cao R, Zhang L, Yang X, Liu J, Xu M, et al. Remdesivir and chloroquine effectively inhibit the recently emerged novel coronavirus (2019-nCoV) in vitro. Cell Res 2020;30:269-71

[23] Jeon S, Ko M, Lee J, Choi I, Byun SY, Park S, et al. Identification of antiviral drug candidates against SARS-CoV-2 from FDA-approved drugs. Antimicrob Agents Chemother 2020;64:e00819-20.

[24] Forrest IS, Bolt AG, Serra MT. Distribution of chlorpromazine metabolites in selected organs of psychiatric patients chronically dosed up to the time of death. Biochem Pharmacol 1968;17:2061-70.

[25] Bickel MH, Graber BE, Moor M. Distribution of chlorpromazine and imipramine in adipose and other tissues of rats. Life Sci 1983;33:2025-31.

[26] Fujii T, Miyazaki H, Nambu K, Matsumoto K, Hashimoto M. Autoradiographic and biochemical studies of drug distribution in the liver. II. [35S]Chlorpromazine and [14C]imipramine. Eur J Drug Metab Pharmacokinet 1984:9:247-55

[27] Sgaragli GP, Valoti M, Palmi M, Frosini M, Giovannini MG, Bianchi L, et al. Rat tissue concentrations of chlorimipramine, chlorpromazine and their $\mathrm{N}$-demethylated metabolites after a single oral dose of the parent compounds. J Pharm Pharmacol 1995;47:782-90.

[28] May PR, Van Putten T, Jenden DJ, Yale C, Dixon WJ. Chlorpromazine levels and the outcome of treatment in schizophrenic patients. Arch Gen Psychiatry 1981:38:202-7

[29] To KK-W, Tsang OT-Y, Leung W-S, Tam AR, Wu T-C, Lung DC, et al. Temporal profiles of viral load in posterior oropharyngeal saliva samples and serum antibody responses during infection by SARS-CoV-2: an observational cohort study. Lancet Infect Dis 2020;20:565-74.

[30] Rundle-Thiele D, Head R, Cosgrove L, Martin JH. Repurposing some older drugs that cross the blood-brain barrier and have potential anticancer activity to provide new treatment options for glioblastoma. Br J Clin Pharmacol 2016;81:199-209.

[31] Wiesel FA, Alfredsson G. The distribution and metabolism of chlorpromazine in rats and the relationship to effects on cerebral monoamine metabolism. Eur J Pharmacol 1976;40:263-72.

[32] Comar D, Zarifian E, Verhas M, Soussaline F, Maziere M, Berger G, et al. Brain distribution and kinetics of 11C-chlorpromazine in schizophrenics: positron emission tomography studies. Psychiatry Res 1979;1:23-9. 
[33] Rogers JP, Chesney E, Oliver D, Pollak TA, McGuire P, Fusar-Poli P, et al. Psychiatric and neuropsychiatric presentations associated with severe coronavirus infections: a systematic review and meta-analysis with comparison to the COVID-19 pandemic. Lancet Psychiatry 2020;7:611-27.

[34] Warren TK, Jordan R, Lo MK, Ray AS, Mackman RL, Soloveva V, et al. Therapeutic efficacy of the small molecule GS-5734 against Ebola virus in rhesus monkeys. Nature 2016;531:381-5.

[35] Acharya UH, Dhawale T, Yun S, Jacobson CA, Chavez JC, Ramos JD, et al. Management of cytokine release syndrome and neurotoxicity in chimeric antigen receptor (CAR) T cell therapy. Expert Rev Hematol 2019;12:195-205.

[36] Hunter BD, Jacobson CA. CAR T-cell associated neurotoxicity: mechanisms, clinicopathologic correlates, and future directions. J Natl Cancer Inst 2019;111:646-54.

[37] Richardson PJ, Ottaviani S, Prelle A, Stebbing J, Casalini G, Corbellino M. CNS penetration of potential anti-COVID-19 drugs. J Neurol 2020;267:1880-2.
[38] Hiemke C, Bergemann N, Clement HW, Conca A, Deckert J, Domschke K, et al. Consensus guidelines for therapeutic drug monitoring in neuropsychopharmacology: update 2017. Pharmacopsychiatry 2018;51:9-62.

[39] Delay J, Deniker P, Harl JM. [Therapeutic use in psychiatry of phenothiazine of central elective action (4560 RP)]. Ann Med Psychol (Paris) 1952;110:112-17.

[40] Committee on Practice Bulletins - ObstetricsACOG Practice Bulletin No. 189: Nausea and vomiting of pregnancy. Obstet Gynecol 2018;131:e15-30.

[41] Gupta M, Davis M, Walsh D, LeGrand S, Lagman R, Parala-Metz A. Nausea and vomiting in advanced cancer - the Cleveland Clinic Protocol (TH310). J Pain Symptom Manag 2013;45:338-9.

[42] Marmura MJ, Silberstein SD, Schwedt TJ. The acute treatment of migraine in adults: the American Headache Society evidence assessment of migraine pharmacotherapies. Headache J Head Face Pain 2015;55:3-20. 